\title{
Studies on gastro-intestinal helminths of Equus acinus in North Gujarat, India
}

\author{
Husen R. Parsani ${ }^{1^{*}}$, Momin R.R. ${ }^{1}$, Lateef A. ${ }^{2}$ \& Hemen Das ${ }^{2}$
}

1 Department of Parasitology; ${ }^{2}$ Department of Animal Physiology \& Biochemistry

College of Veterinary Science \& Animal Husbandry, Sardarkrushinagar Dantiwada Agricultural University, Sardarkrushinagar, Dantiwada-385506, Gujarat, India

\begin{abstract}
A year round study (October to September) was conducted in the districts of North Gujarat (India) to identify the gastro-intestinal helminths of donkeys (Equus acinus), determine prevalence and correlate haematological parameters with parasite burdens. A total of 1794 faecal samples of donkeys contained the following helminths (prevalence \% in brackets): Strongyloides westeri (17.2), Parascaris equorum (23.8), Strongylus sp. (55.3), an amphistome digenean (1.5), Anoplocephala sp. (1.0), Balantidium coli (13.1) and Eimeria leuckarti (7.0). Overall prevalence was 75.9 with a mean of 627 (50-1650) eggs per gram faeces. Seasonally the maximum prevalence (85.3) occurred in March and minimum (65.2) in July. 14\% of donkeys were considered to be severely infected, $38 \%$ heavily, $36 \%$ moderately and $12 \%$ mildly infected. Larval cultures revealed the presence of (prevalence\%): Cyathostomum sp. (48), Gyalocephalus sp. (8), Oesophagodontus sp. (6), Triodontophorus sp. (10), Strongyloides westeri (10), Strongylus vulgaris (30), Strongylus equines (40) and S. edentatus (30). Hematological indices were inversely proportional to epg counts.
\end{abstract}

Keywords: donkeys, gastro-intestinal parasites, haematology, prevalence.

\section{Introduction}

The donkey (Equus acinus) has been a beast of burden for thousands of years, often as a creature of abject slavery, overladen, underfed and ill-used: "to the smallest ass shall go the biggest stick." However, in spite of mechanization throughout the world, the donkey is one of the most under-appreciated but important draught animal, serving a key role in the agricultural economy of the developing world. It is estimated that 50 per cent of the energy required for agricultural production in the world is derived from animals, and the donkey is a major contributor to this need.

Donkeys need little attention and small quantities of food to provide sustained work on poor forage with little rest. As a result, they are considered to be excellent pack animals for transporting heavy loads in the hills, desert and plain areas in countries such as India, Egypt, Sudan, Somalia, Persia and China. In tropical countries such as India, they are the cheapest and easiest means of transport, suiting needs of washer man, potters, house builders, brick manufactures and Vanjara engaged in earth work till today (Mwenya \& Tandkeib 2004). There are about 40 million donkeys in developing countries, the full potential use of which still remains to be exploited. According to FAO (2002) census, India's donkey population is 300,000 , constituting $2.25 \%$ of the total world population. The donkey population of Gujarat is about 80,155 constituting $27 \%$ of the Indian donkey population. Thus donkeys contribute immensely in the overall economic development of India, especially in rural areas of Gujarat.

In spite of their paramount economic importance, due attention has not been paid to the conservation of Indian donkey breeds and to upgrade them by undertaking breeding programmes and health management. Even today the stoic, hardworking donkey is often misunderstood by its owner and unfortunately often by veterinarians worldwide. Being very

* Author for correspondence: tel +919426705362 email : husen46@gmail.com 
poor, donkey keepers often have a myopic attitude regarding the health of their animals. This has resulted into considerable reduction in their work output, reproductive performance and longevity. Donkeys are vulnerable to an array of diseases of biological origin: parasitic, bacterial, fungal and viral diseases. Among parasitic diseases, babesiosis, trypanosomiasis and gastro-intestinal strongylosis are considered to be silent killers (Mekebib et al. 2010). Parasitic infections are common and varied, exercising a great influence on the performance of donkeys.

The attention given by governmental and non-governmental organizations to donkeys has been far below what they deserve. Despite their huge numbers and increasing importance in the Indian economy, knowledge about the health problems affecting the welfare of donkeys is limited for most parts of the country. Therefore the objectives of this study were to determine the spectrum of species and prevalence of the major gastro-intestinal parasites of donkeys, their seasonal pattern and to test for their association with measurable haematological parameters.

\section{Materials \& Methods}

The study was conducted from October to the following September in the Banaskantha, Sabarkantha, Mehsana and Patan districts of North Gujarat, India $\left(20^{\circ}\right.$ to $35^{\circ} \mathrm{N}, 71^{\circ}$ to $\left.73^{\circ} \mathrm{E}\right)$, within the tropical region where the climate is arid to semi-arid, with less precipitation than other areas of Gujarat. In North Gujarat, summer starts in March/April and ends in June, followed by the south-western monsoon. The extreme conditions rise above $40^{\circ} \mathrm{C}$ in summer, and fall to $5^{\circ} \mathrm{C}$ in winter. The long rainy season is between June and October, with an average rainfall of $480 \mathrm{~mm}$.

Feeding and management practices are not established for domesticated donkeys, so they were kept solely on grazing with no extra fodder provided. No de-worming or vaccination was carried out during the study period.

A total of 1794 faecal samples were collected and subjected to quantitative and qualitative coprological examination to identify the major gastro-intestinal parasites involved, determine their prevalence and find out their association with haematological parameters. The donkey keepers selected for the study were informed of the importance of the study, and asked to present their donkeys on specific visit dates and places. Faecal samples were taken directly from the rectum or the ground when the animal was seen defecating. Under strict sanitation, samples were placed in air- and water-tight vials and brought to the laboratory. Gross faecal examinations were carried out before being subjected to detailed examination under the microscope. The modified McMaster and Bearman techniques, and sedimentation and floatation methods, were used to identify and count the helminth eggs and larvae (Urquhart et al. 1996). Faecal cultures $(\mathrm{n}=100)$ were carried out for samples with total mean egg counts greater than 500. Identification of larvae $\left(\mathrm{L}_{3}\right)$ was based on specific morphological traits. Levels of worm infection were extrapolated from the infection severity index defined by Soulsby (1986) where horses were said to have mild, moderate, heavy and severe nematode infestations if their faecal egg counts were less than 500, 800-1000, 1100-1500 and more than 1500 , respectively.

Blood samples were collected aseptically from the jugular vein with the help of vacuette needles (20G). Nine $\mathrm{ml}$ of blood was drawn into each vacuette EDTA (Greinerbio-one), labelled and transported to the laboratory in an icebox. Haematological analyses comprised of of haemoglobin, total erythrocyte count, total leucocyte count, packed cell volume, erythrocyte sedimentation rate and differential leucocyte count, and were carried out according to the method described by Jain (1986). The data were analyzed using Student's t- test as described by Snedecor \& Cochran (1989). 


\section{Results}

The prevalence of gastro-intestinal helminthic infection in donkeys was almost $76 \%$, with a mean of 627 (range 50-1650) eggs per gram of faeces (Table 1), and was similar in all the districts of North Gujarat studied. Overall monthly prevalence reached a maximum in March and minimum in July (Table 1). The species found were Strongyloides westeri (Fig. 6), Parascaris equorum (Fig. 1), Strongylus sp. (Figs. $2 \& 3$ ), an unidentified amphistome digenean, Anoplocephala sp. (Fig. 5), Balantidium coli (Fig. 7) and Eimeria leuckarti (Fig. 4): their prevalences are given in Table 1. Comparatively greater helminth prevalence was recorded in the period January to April than in May to July. The greatest overall prevalence was of strongylosis at a maximum of $55.3 \%$ (Table 1 ).
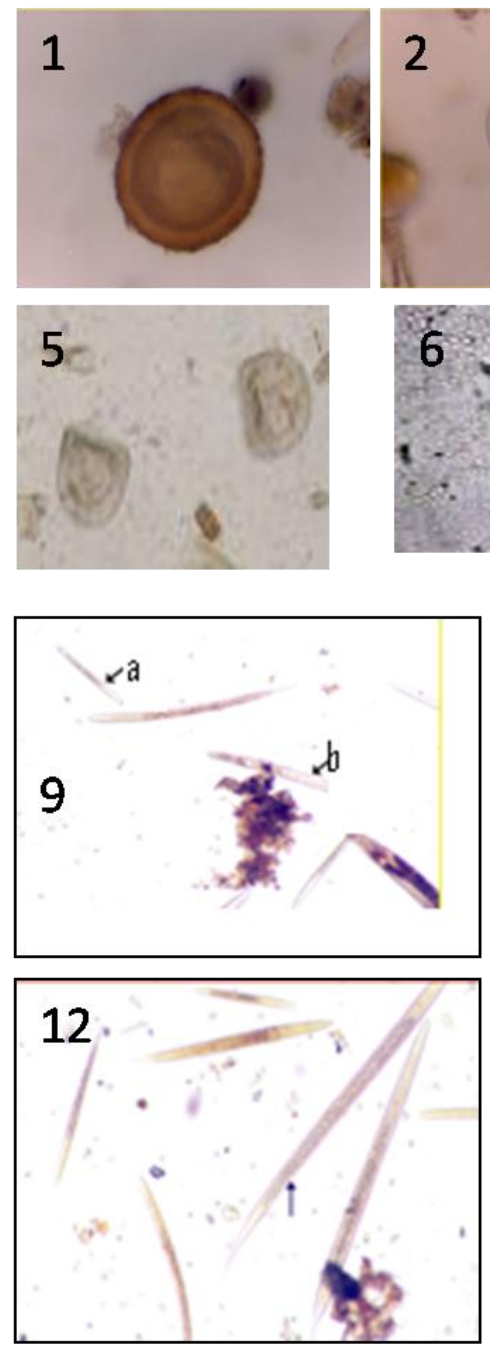
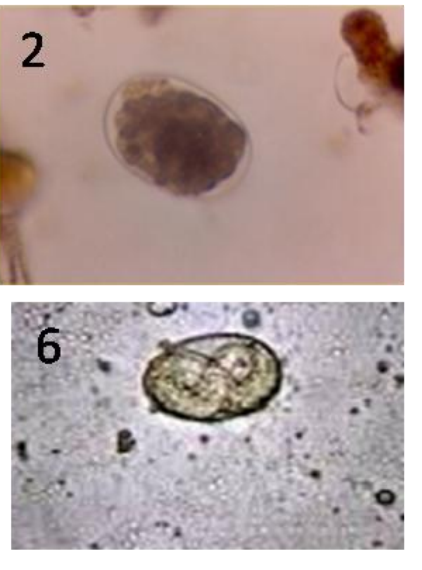
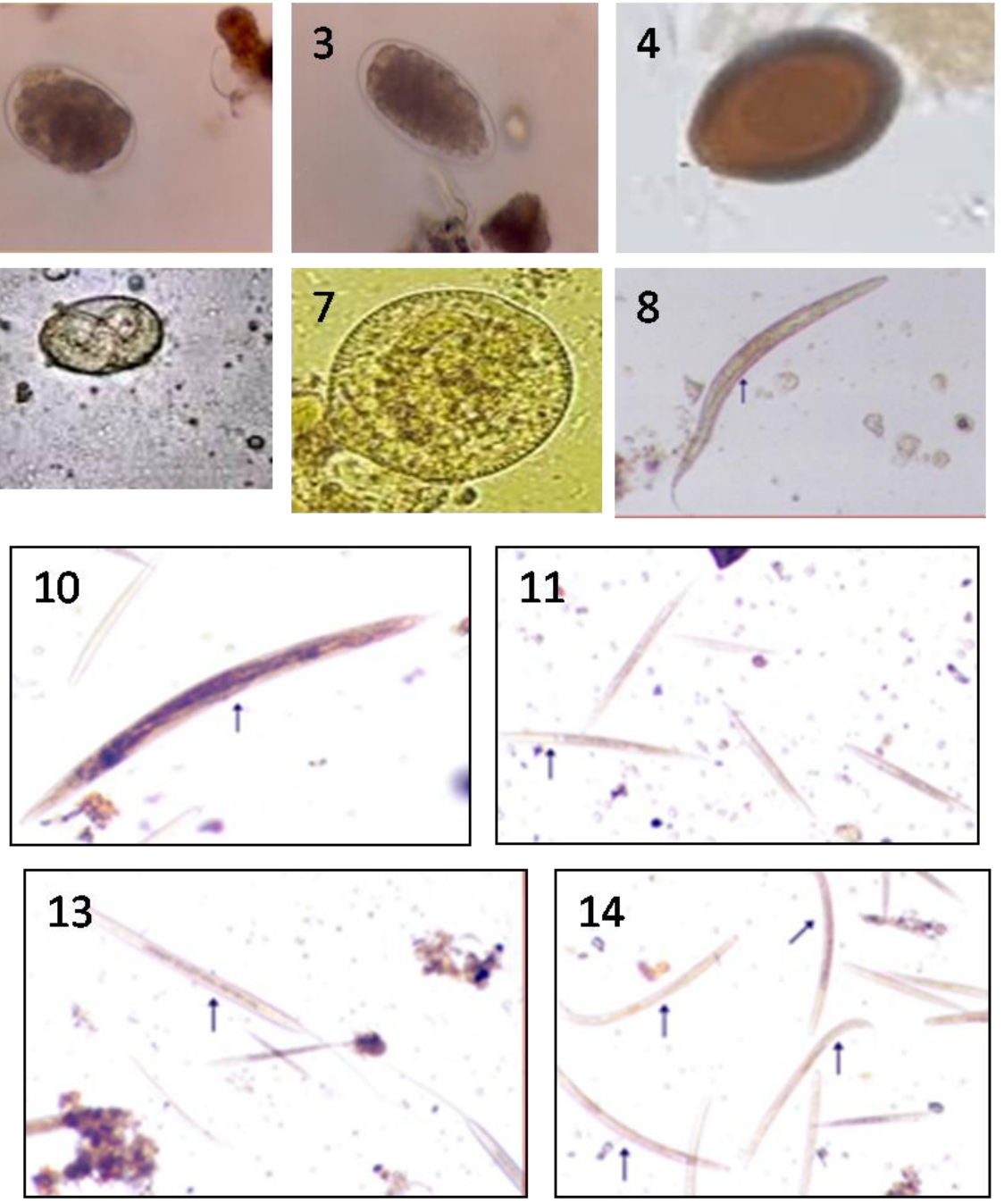

Figures: 1) ova of Parascaris equorum; 2) ova of Strongylus sp.; 3) ova of Strongylus sp.; 4) oocyst of Eimeria leuckarti; 5) ova of Anoplocephala sp.; 6) ova of Strongyloides westeri; 7) cyst of Balantidium coli; 8) larvae of Cyathostome sp.; 9) larvae of (a) Gyalocephalus sp. and (b) Oesophagodontus sp.; 10) larvae of Triodontophorus sp.; 11) larvae of Strongyloides westeri; 12) larvae of Strongylus vulgaris; 13) larvae of Strongylus equinus; 14) larvae of Strongylus edentatus. 


\begin{tabular}{|c|c|c|c|c|}
\hline Month & $\mathbf{N}$ & $\begin{array}{l}\text { positives } \\
(\%)\end{array}$ & $\begin{array}{c}\text { Mean EPG } \\
\text { (range) }\end{array}$ & $\begin{array}{c}\text { Species detected } \\
\text { (prevalence \%) }\end{array}$ \\
\hline June & 150 & $\begin{array}{r}104 \\
(69.3)\end{array}$ & $\begin{array}{c}513.6 \\
(100-1150)\end{array}$ & $\begin{array}{l}\text { Strongyloides (25), Parascaris equorum (29), Strongylus } \\
\text { (71), Balantidium coli (23), Eimeria leuckarti (8), } \\
\text { amphistome (3), Anoplocephala sp. (2). }\end{array}$ \\
\hline July & 155 & $\begin{array}{r}101 \\
(65.2)\end{array}$ & $\begin{array}{c}572.1 \\
(50-1150)\end{array}$ & $\begin{array}{l}\text { Strongyloides (21), Parascaris equorum (30), Strongylus } \\
(71), \text { amphistome (4), Balantidium coli }(21), \text { Eimeria } \\
\text { leuckarti (14), Anoplocephala sp. (1) }\end{array}$ \\
\hline August & 157 & $\begin{array}{r}112 \\
(71.3)\end{array}$ & $\begin{array}{c}646.5 \\
(50-1450)\end{array}$ & $\begin{array}{l}\text { Strongyloides (24), Parascaris equorum (35), Strongylus } \\
\text { (80), Balantidium coli (23), Eimeria leuckarti (11), } \\
\text { Anoplocephala sp. (2), amphistome (2) }\end{array}$ \\
\hline September & 150 & $\begin{array}{r}124 \\
(82.7)\end{array}$ & $\begin{array}{c}688.3 \\
(150-1450)\end{array}$ & $\begin{array}{l}\text { Strongyloides }(30), \text { Parascaris equorum (41), Strongylus } \\
\text { (92), Balantidium coli (22), Eimeria leuckarti (14), } \\
\text { amphistome (3) }\end{array}$ \\
\hline October & 146 & $\begin{array}{r}115 \\
(78.8)\end{array}$ & $\begin{array}{c}635.4 \\
(100-1650)\end{array}$ & $\begin{array}{l}\text { Strongyloides (26), Parascaris equorum (9), Strongylus (23), } \\
\text { Balantidium coli (4), Eimeria leuckarti (1), Anoplocephala } \\
\text { sp. (1) }\end{array}$ \\
\hline November & 145 & $\begin{array}{r}102 \\
(70.3)\end{array}$ & $\begin{array}{c}563.1 \\
(100-1250)\end{array}$ & $\begin{array}{l}\text { Strongyloides (24), Parascaris equorum (32), Strongylus } \\
\text { (76), Balantidium coli (15), Eimeria leuckarti (6), } \\
\text { amphistome ( } 3 \text { ) }\end{array}$ \\
\hline December & 146 & $\begin{array}{r}103 \\
(70.6)\end{array}$ & $\begin{array}{c}511.8 \\
(100-1250)\end{array}$ & $\begin{array}{l}\text { Strongyloides (22), Parascaris equorum (35), Strongylus } \\
\text { (78), Balantidium coli (14), Eimeria leuckarti (9), } \\
\text { amphistome (2), Anoplocephala } \mathrm{sp.}(1)\end{array}$ \\
\hline January & 140 & $\begin{array}{r}114 \\
(81.4)\end{array}$ & $\begin{array}{c}683.8 \\
(50-1650)\end{array}$ & $\begin{array}{l}\text { Strongyloides (29), Parascaris equorum (38), Strongylus } \\
\text { (80), Anoplocephala } \mathrm{sp} .(3), \text { Balantidium coli (15), Eimeria } \\
\text { leuckarti (8), amphistome ( } 2)\end{array}$ \\
\hline February & 149 & $\begin{array}{r}125 \\
(83.9)\end{array}$ & $\begin{array}{c}682.3 \\
(100-1500)\end{array}$ & $\begin{array}{l}\text { Strongyloides (28), Parascaris equorum (43), Strongylus } \\
\text { (94), Eimeria leuckarti (12), Anoplocephala sp. (2), } \\
\text { Balantidium coli (25), amphistome (2) }\end{array}$ \\
\hline March & 163 & $\begin{array}{r}139 \\
(85.3)\end{array}$ & $\begin{array}{c}736.8 \\
(150-1650)\end{array}$ & $\begin{array}{l}\text { Strongyloides }(34), \text { Parascaris equorum (40), Strongylus } \\
\text { (98), Balantidium coli (22), Eimeria leuckarti (11), } \\
\text { Anoplocephala } \mathrm{sp.} \text { (3), amphistome (3) }\end{array}$ \\
\hline April & 147 & $\begin{array}{r}123 \\
(83.7)\end{array}$ & $\begin{array}{c}746.6 \\
(50-1600)\end{array}$ & $\begin{array}{l}\text { Strongyloides (24), Parascaris equorum (37), Strongylus } \\
\text { (87), Eimeria leuckarti (13), Anoplocephala sp. (1), } \\
\text { Balantidium coli (24), amphistome (1) }\end{array}$ \\
\hline May & 146 & $\begin{array}{r}100 \\
(68.5)\end{array}$ & $\begin{array}{c}539.3 \\
(100-1000)\end{array}$ & $\begin{array}{l}\text { Strongyloides (22), Parascaris equorum (30), Strongylus } \\
\text { (79), Balantidium coli (17), Eimeria leuckarti (10), } \\
\text { amphistome ( } 2)\end{array}$ \\
\hline Overall & 1794 & $\begin{array}{r}1362 \\
(75.9)\end{array}$ & $\begin{array}{c}626.6 \\
(50-1650)\end{array}$ & $\begin{array}{l}\text { Strongyloides (17.2) Parascaris equorum (23.8), Strongylus } \\
\text { (55.3), Eimeria leuckarti (7.0), Anoplocephala sp. (1.0), } \\
\text { Balantidium coli (13.1), amphistome (1.5) }\end{array}$ \\
\hline
\end{tabular}

Table 1: Occurrence and prevalence of helminthic infections in the donkeys of North Gujarat each month through the year: 'amphistome' means a digenean with an oral sucker and a posterior acetabulum.

In the faecal cultures, eight remarkably different types of larval helminth parasites were identified, with both large and small strongyles almost equally prevalent in all districts: Cyathostomum sp. (48\%) (Fig. 8), Gyalocephalus sp. (8\%) (Fig. 9a), Oesophagodontus sp. (6\%) (Fig. 9b), Triodontophorus sp. (10\%) (Fig. 10), Strongyloides westeri (10\%) (Fig. 11), 
Strongylus vulgaris (30\%) (Fig. 12), Strongylus equinus (40\%) (Fig. 13) and Strongylus edentatus (30\%) (Fig. 14).

The haematological profiles of three groups of donkeys were studied: uninfected $(\mathrm{n}=$ $50)$; and infected $(\mathrm{n}=50)$, divided into those with less than 500 eggs per gram faeces, and those with more than 500 eggs per gram (Table 2). There was a significant decrease in mean haemoglobin concentration with greater severity of infection, and a similar declines in the mean total erythrocyte count and packed cell volume (Table 2). There were other apparent increases and decreases between groups, but none were statistically significant.

\begin{tabular}{lccc}
\hline & Uninfected & \multicolumn{2}{c}{ Infected } \\
\cline { 3 - 4 } Parameter & & $<\mathbf{5 0 0}$ epg & $>\mathbf{5 0 0}$ epg \\
\hline Haemoglobin concentration $\left(\mathrm{g} \mathrm{dl}^{-1}\right)$ & $11.4 \pm 0.2^{\mathrm{a}}$ & $9.3 \pm 0.1^{\mathrm{b}}$ & $7.7 \pm 0.2^{\mathrm{c}}$ \\
Total leucocyte count & $13454 \pm 480$ & $13264 \pm 454$ & $13856 \pm 726$ \\
Total erythrocyte count $\left(10^{6} \mathrm{kl}^{-1}\right)$ & $5.2 \pm 0.1^{\mathrm{a}}$ & $4.7 \pm 0.05^{\mathrm{b}}$ & $4.1 \pm 0.1^{\mathrm{c}}$ \\
Erythrocyte sedimentation rate & $84.2 \pm 5.7$ & $93.6 \pm 7.5$ & $107.8 \pm 7.9$ \\
Packed cell volume $(\%)$ & $40.5 \pm 0.4^{\mathrm{a}}$ & $34.5 \pm 0.2^{\mathrm{b}}$ & $29.3 \pm 1.0^{\mathrm{c}}$ \\
Neutrophils & $55.0 \pm 1.8$ & $53.8 \pm 1.7$ & $56.5 \pm 2.2$ \\
Lymphocytes & $38.9 \pm 1.7$ & $39.5 \pm 1.8$ & $36.9 \pm 2.2$ \\
Eosinophils & $5.6 \pm 0.5$ & $5.8 \pm 0.7$ & $6.1 \pm 0.8$ \\
Monocytes & $0.58 \pm 0.11$ & $0.61 \pm 0.07$ & $0.50 \pm 0.13$ \\
\hline
\end{tabular}

Table 2: Haematological values in uninfected and infected animals divided in low and high infections according to the number of eggs per gram of faeces (epg). Superscript letters denote means that are significantly different $(\mathrm{p}<0.05)$ across a row.

\section{Discussion}

While gross faecal examinations showed no evidence of gastro-intestinal parasites, microscopic examinations showed that gastro-intestinal parasitosis was actually an important disease in the study area, with an overall prevalence of more than $75 \%$. Based on the severity index defined by Soulsby (1986), 14\% of the donkeys were severely infected, $38 \%$ heavily infected, 36\% moderately infected and 12\% mildly infected. All districts showed the same prevalences. Others have also reported the prevalence of helminthic infections in donkeys of between $73 \%$ and $90 \%$ in India (Pal 2002, Getachew et al. 2011), and from $48 \%$ to $100 \%$ abroad (Ayele et al. 2006). Our quantitative levels of infection closely resemble those of Chander \& Kumar (2000), who reported 90\% prevalence with mean epg of $580 \pm 38$ in Hisar, India. Maintenance of the high infection rate in North Gujarat may be associated with the lack of any intervention programme, coupled with the grazing management system whereby donkeys are allowed to graze together on small plots of land throughout the year, facilitating contamination between animals.

The prevalence of strongyle infections was $55 \%$, almost the same in the four districts of North Gujarat. Other workers have reported between $8 \%$ and $89 \%$ prevalence of Strongylus spp. from India (Pal 2002), and similar high levels abroad (Ayele et al. 2006). From the seasonal variation of strongyle infestation, treatment schedules that enable the elimination of the parasites at peak infection and prevent re-infection of pastures can be proposed. Troney (1989) has proposed two treatment schedules per year with broad-spectrum anthelmintics for tropical conditions. A treatment may be given at the end of the rainy season. At this time, the animals are well-nourished and may harbour large number of parasites without being seriously 
affected. Eliminating these parasites will improve the adaptation of the animals to the harsh dry-season conditions. Another treatment can be given at the end of the dry season. This treatment reduces infestation of pastures at the time of first rains by residual parasites.

The prevalence of Parascaris equorum was about 24\%, similar to earlier reports (Lyons et al. 1984, Bhat \& Sharma 1990, Chander \& Kumar 2000) of $18-31 \%$. However, Wadhwa et al. (1993) has reported much lower prevalences of $4-17 \%$ in Himachal Pradesh, but used a smaller sample size. Levels of infestation did not vary seasonally.

The prevalence of Strongyloides westeri $(17 \%)$ is about the same as in Chander \& Kumar (2000), but lower than the figures (28-38\%) of Ayele et al. (2006). The low prevalence in our study area may be the effect of its relatively higher temperatures, which desiccate the highly susceptible eggs and larvae of Strongyloides westeri.

The prevalence of the amphistome digenean and Anoplocephala sp. were low, in the later case perhaps due to the seasonality of its oribatid mite vectors (Soulsby 1986). The low prevalence of the amphistome digenean might be due to differences in ecological preference for the development of the snail intermediate hosts and the parasite. Wadhwa et al. (1993) also reported similarly low prevalences in Himachal Pradesh, but in Haryana much higher prevalences $(7-31 \%)$ have been reported (Sengupta \& Yadav 1998) due to the snail population and favourable environmental conditions in the northern part of the country. Our estimates for Anoplocephala sp. are similar to those of Sengupta \& Yadav (1998), but much lower than some others (Lyons et al. 1984, 2000, Pearson et al. 1993, Fogarty et al. 1994), where levels reach $80 \%$, perhaps because of the availability of the intermediate oribatid mite host in favourable environmental conditions. The prevalences of Balantidium coli and Eimeria leuckarti were similar to those of Sengupta \& Yadav $(1998,2003)$.

In this study, another striking feature was the low prevalence $(55 \%)$ of large strongyles. Amongst various possible factors, adverse environmental conditions for survival of the extrinsic stages of the parasite as well as the inability of large strongyles to undergo inhibition inside the host and their long generation interval might be responsible for such low prevalence (Pal 2002). The degree of infection and prevalence were similar in all four districts of North Gujarat, and there was little seasonal fluctuation but infection loads were reduced in dry conditions. Thus we attribute the low prevalence to the unfavorable environmental conditions prevailing in North Gujarat, which experiences intermittent low rainfall, and high humidity as well as temperature throughout the year. This can further be appreciated by comparison of the meteorological data and the percent positive animals studied in the four districts.

The overall seasonal prevalence (Table 1) of helminthic infection, with a maximum in March and minimum in July, was similar in the four districts. The maximum might be caused by the resumption of development of the hypobiotic larvae $\left(\mathrm{L}_{4}\right)$ after the chill of winter. This view is supported by Pal (2002) and Mulate (2005), who indicated that faecal egg counts begin to rise to severe levels during the wet season. This could be because of the long pre-patent period of strongyles, which ensures that larvae acquired in one grazing season only reach maturity during the next (Urquhart et al. 1996). The lowest intensity of infection during May to July was due to larval inhibition because of unfavourable climatic conditions outside the host (Pal 2002, Ayele et al. (2006).

The significant reductions in haemoglobin, total erythrocyte count and packed cell volume indicate normocytic normochromic anaemia, perhaps due to blood loss from ingestion of erythrocytes by the immature Strongylus sp. and probably the reduced haemopoiesis as a result of poor metabolism and poor nutrition status. Haematological changes from direct loss of whole blood by nematodes has been postulated for sheep and other animals (Soulsby 1986). Although non-significant here, in other studies increases in the erythrocyte sedimentation rate have been associated with extensive tissue damage in the intestine and liver caused by larval migration, shown in donkeys (Varshney \& Uppal 1992), camels (Suchitra Sena et al. 2000), cattle (Rajkhowa et al. 2004) and sheep (Padmaja et al. 2006). 
Further study of donkeys aimed at early detection of parasitic infection, or better management and control of parasitic infections, is clearly required. Studies are also required on the impact of parasitic infections on the health status, working efficiency, reproductive efficiency, draftability and longevity of donkeys. Periodic faecal examination and deworming should be carried out at regular intervals to control parasitic infections for better improvement of health status of donkeys, and for the welfare of nomadic tribes that rely on donkeys. Governmental or non-profit development agencies should include donkeys in their priorities for research to develop strategies for sustainable and integrated disease prevention and control programs that are practical for developing communities.

\section{Acknowledgements}

The authors gratefully acknowledge the cooperation and support of the donkey keepers in carrying out the study. The authors are also grateful to the Dean of the College of Veterinary Science \& A.H. for permission to undertake the study. Thanks are also due to the Head of the Department of Parasitology for providing facilities for the study.

\section{References}

Ayele G, Feseha G, Bojia E \& Joe A (2006) Prevalence of gastro-intestinal parasites of donkeys in Dugda Bora District, Ethiopia. Livestock Research for rural Development 18(10) : 124-133.

Bandopadhyay B \& Dasgupta CK (2005) Haematological changes in trichostrongylosis of calves treated with different anthelmintics. Journal of Veterinary Parasitology 19(2) : 123-124.

Bhat TK \& Sharma RL (1990) Ivermectin: haematobiochemical evaluation of its anthelmintic activity against experimental Dictyocaulus filaria infection in sheep. Indian Veterinary Journal 67: 10-16.

Chander R \& Kumar R (2000) Prevalence of gastrointestinal parasites in donkeys at Hisar (Haryana). Compendium 11th National Congress of Veterinary Parasitology, Bhubneswar, February 4-6. pp. 62-63.

Fogarty U, del Piero F, Purnell RE \& Mosurski KR (1994) Incidence of Anoplocephala perfoliata in horses examined at an Irish abattoir. The Veterinary Record 134: 515-518.

Getachew M, Trawford A, Feseha G \& Reid SWJ (2011) Gastrointestinal parasites of working donkeys of Ethiopia. Global Veterinaria 6(3): 223-227.

Jain NC (1986) Scham's Veterinary Haematology. $4^{\text {th }}$ Edn. Lea \& Febiger, Philadelphia. USA.

Lyons ET, Drudge JH, Tolliver SC, Swerczek TW \& Crowe MW (1984) Prevalence of Anoplocephala perfoliata and lesions of Draschia megastoma in thoroughbreds in Kentucky at necropsy. American Journal of Veterinary Reearch, 45(5): 996-999.

Lyons ET, Swerczek TW, Tolliver SC, Bair HD, Drudge JH \& Ennis LE (2000) Prevalence of selected species of internal parasites in equids at necropsy in central Kentucky (1995-1999). Veterinary Parasitology 92: 51-62.

Mekibib B, Manegerew M, Tadesse A, Abuna F, Megersa B, Regassa A, Mekuria S \& Abebe R (2010) Prevelence of haemoparasites and associated risk factors in working donkeys in Adigudem and Kwiha Districts of Tigray Region, Northern Ethiopia. Journal of Animal \& Veterinary Advances 9(17): 2249-2255.

Mwenya E \& Tandkeib G (2004) History and utilization of donkey in Namibia. pp 172- 174 in Starkey P \& Fielding D (eds) Donkeys, people and development. A resource book of the animal traction network for Eastern and Southern Africa. ACP-EU Technical center for Agricultural and and Rural cooperation (CTA), Wageningen. The Netherlands

Mulate, B, (2005). Preliminary study on helminthosis of equines in South and North Wollo zones. Journal of Veterinary Association. 9 (2): 25-37.

Padmaja, B.; Satish Kumar, K. and Haritha, C. (2006). Haematological and blood biochemical profile of sheep with mixed endoparasitic infestation. Indian Vet. J., $83: 634-636$.

Pal, D. (2002). Equine strongyles- epidemiology, anthelmintic efficacy and resistance. M.V.Sc. Thesis, Submitted to the Govind Ballabh Pant University of Agriculture and Technology, Pantnagar, Uttaranchal, India.

Pearson, G.R.; Davies, L.W.; White, A.L. and O'Brien, J.K. (1993). Pathological lesions associated with Anoplocephala perfoliata at the ileo-caecal junction of horses. The Vet. Rec., 132 : 179-182

Rajkhowa, S.; Bujarbaruah, K.M. and Rajkhowa, C. (2004). Haematobiochemicalchanges in ascariosis of Mithun calves. Indian Vet. J, 81: 571-572.

Sengupta, P.P. and. Yadav, M.P. (1998). Incidence of gastrointestinal parasites in organized and unorganized equid farms of Haryana. Indian J. Anim. Sci., 68:1218-1220.

Sengupta, P.P. and Yadav, M.P. (2003). Prevalence of gastro-intestinal helminths in equines in some hilly pockets of Western Himalayas. Indian J. Anim. Sci., 73 (4) : 394-396.

Snedecor, G.W. and Cochran, W.G. (1989). Statistical Method. $8^{\text {th }}$ Edn. Oxford and IBH Publishing Co., New Delhi. 
Soulsby, E.J.L. (1986). Helminths, Arthropods and Protozoa of Domesticated Animals. $7^{\text {th }}$ Edn. pp. 1-809. The ELBS, Bailliere \& Tindall, London.

Suchitra S. D., Mal, G.; Kumar, R. and Sahani, M.S. (2000). Prevalence, haematobicchemical studies and chemotherapy of gastrointestinal nematode infection in camels. J. Vet. Parasitol, 14: 151-153.

Troney P.M. (1989). Helminths of Livestock and poultry in tropical Africa. In: Manual of Tropical Veterinary parasitology. The Technical center for Agricultural and Rural Co-operation ( CTA). PP .1-178, CAB International, Walling ford, Oxon OX10 8DE, UK.

Urquhart, G.M.; Armour J.; Duncan J.L.; Dunn A.M. and Jennings F.W.(1996) Veterinary Parasitology. $2^{\text {nd }}$ ed. 307p. Black well Science limited, London.

Varshney. J.P. and Uppal, P.K. (1992). Incidence, periodicity and haematobiochemical changes in equines naturally infected with microfilariae of Setaria equines. J. Vet. Parasitol., 6 (2): 1-4.

Wadhwa. D.R.; Prasad, B.; Mandial, R.K. and Rao, V.N. (1993). Endoparasitism in equines of Himachal Pradesh - its prevalence and clinical appraisal. Centaur $10(1): 10-12$.

$$
\begin{aligned}
& \text { الملخص العربي - المي } \\
& \text { دراسات على الديدان المعوية والمعدية فى أحد أنواع الحمير (إيكيس أسنيس) فى شمال جيشارات ــ الهند }
\end{aligned}
$$

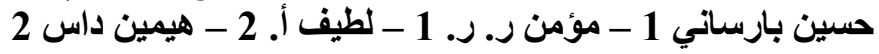

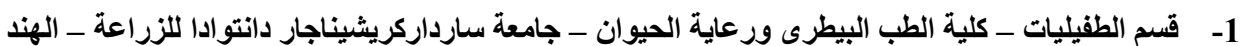

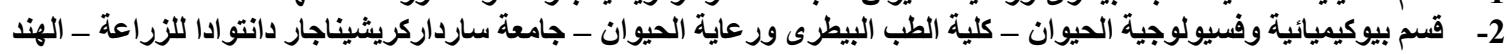

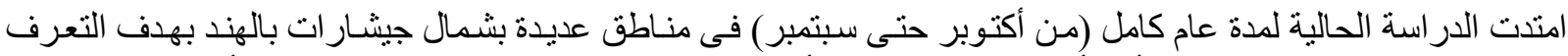

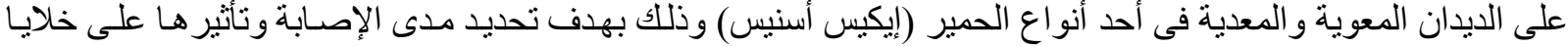

$$
\begin{aligned}
& \text { الدم. لقد تم فحص إجمالي } 1794 \text { عينة من روث تلك الحمير و التى احتوت على النسب التالية من الطفيليات: }
\end{aligned}
$$

